\title{
Identify Indonesian Psychology Publications in PsycINFO Database: A Scoping Review
}

\author{
Indra Yohanes Kiling \\ Institute of Resource Governance and Social Change \\ School of Psychology \\ The University of Adelaide
}

\author{
Beatriks Novianti Bunga \\ Faculty of Teachers Training \\ Universitas Nusa Cendana
}

\begin{abstract}
Psychology field in Indonesia has grown for years and its publications have spread in various academic media. The aim of this study was to locate existing literature in a database with solid reputation to give insight about the current progress of psychology in Indonesia. A literature search of PsycINFO database was performed. There were no date or language restrictions. Narrative analysis was used to synthesize findings. Seventy articles were identified from the search terms and four articles were considered relevant. Three of the four relevant studies were focused in the subfield of cross-cultural psychology. Some patterns of publishing in both relevant and irrelevant articles were found and discussed. This study is considered among the first scoping study that has been done in Indonesian context.
\end{abstract}

\section{Keywords: scoping review, psychology, Indonesia}

Ilmu psikologi telah berkembang setelah sekian tahun dan publikasinya telah menyebar di berbagai media ilmiah. Tujuan penelitian ini adalah untuk mengidentifikasi literatur yang ada di dalam pangkalan data dengan reputasi yang baik untuk memberikan wawasan tentang perkembangan ilmu psikologi di Indonesia. Pencarian literatur dilakukan di pangkalan data PsycINFO. Tidak ada pembatasan terkait waktu dan bahasa publikasi. Analisis naratif digunakan untuk menyintesis temuan. Tujuh puluh artikel diidentifikasi dan empat artikel dianggap relevan. Tiga dari empat studi relevan berfokus dalam bidang psikologi lintas budaya. Beberapa pola publikasi dalam artikel yang relevan dan tak-relevan juga berhasil dianalisis dan didiskusikan. Penelitian ini dianggap sebagai salah satu scoping review pertama yang dilakukan dalam konteks Indonesia.

Kata kunci: telaah bidang, psikologi, Indonesia

History of the psychology field in Indonesia can be traced back in the era prior to independence. Psychology was not taught as a stand-alone discipline but was only introduced in relation to educational theory in colleges for teachers and also as depth psychology in medical schools (Munandar \& Munandar, 1987). The first degree program in Psychology was offered by the Department of Psychology under the Faculty of Medicine at Universitas Indonesia. This Department later became an independent faculty back in 1960

The first author would like to acknowledges support from the Indonesia Endowment Fund for Education (LPDP). The first and second author also acknowledges support from fellow researchers in BUNGA research community, based in Kupang.

Correspondence concerning this article should be addressed to Indra Yohanes Kiling, Hughes Building Room 721c, School of Psychology, University of Adelaide. Adelaide, 5000. E-mail: iykiling@gmail.com
(Munandar \& Munandar, 1987). From there, the psychology academic field continuously expanded. Another Faculty of Psychology was founded at Padjadjaran University in 1960 and also at Gadjah Mada University in 1965 (Prawitasari-Hadiyono, 1998). In 2013, at least 93 psychology faculties has been running in Indonesia, consisting of 18 faculties located at public universities and 75 faculties at private universities (HIMPSI, 2013)

Academic journal is an academic community, consisting of the editors, writers, and readers (Prawitasari, 2006). The latest progress of a knowledge field can be discovered from empirical research published in academic journals. The quality from its articles is the very symbol of the journal, while the consistency and caliber of its journals represents the impact of a field of knowledge. By browsing good 
quality journals, we can discover the latest research in a broad scope or in a specific sub-field.

Almost every psychology faculties in Indonesia has a journal of itself. Some of them even have several journals published like Faculty of Psychology at Ahmad Dahlan University. Some journals are consistently accredited by Indonesian Directorate General of Higher Education (DIKTI), such as ANIMA Indonesian Psychological Journal of Universitas Surabaya and Jurnal Psikologi of Gadjah Mada University. The accreditation indicates the high quality and impact of the journal and articles published by it. Lecturers and researchers from all around Indonesia compete to publish their article in these particular journals, sometimes resulting in the weakening of other existing journals because most of good research articles are absorbed into these high quality journals.

As the field constantly improves, psychology scholars in Indonesia also start to aim higher in terms of publication. Encouraged from the satisfaction of publishing knowledge in a broader community and also reward (points needed for promotion) from DIKTI, these scholars make international journals as their designated target of publication. Unfortunately, publishing articles in an English language journal does not always translate as high quality publication. There are a lot of predator journals that could "devour an article into nothingness." These journals typically charge fees to authors without providing editorial and also sometimes the publishing service (Beall, 2015). Jeffrey Beall, a librarian that is quite famous for his effort in combat the predator journals, has indicated that the number of predator journals is constantly rising over years (Beall, 2015). This problem could bring a lot of trouble to those early career psychology scholars in Indonesia if they are not cautious.

Aside from the potential problem, the emerging spirit of publishing internationally by Indonesian psychology scholars should be treated positively. By learning from research articles published by Indonesian scholars in high quality journals, we can get a better understanding of how far the field of psychology has been developing in Indonesia. Unfortunately, a systematic search and report of good research articles published by Indonesian scholars in high quality journals cannot be found in the existing literature. Therefore, a scoping review is needed to locate these articles and to identify the pattern of published studies.

The pattern identified from this study will help Indonesian scholars to know better the kind of studies that have been published in high quality journals that is indexed by a reputable database. This information will help them to produce a high quality article themselves. The review will focus on a research question: "What is known from the existing literature in PsycINFO database about articles published by Indonesian scholars?" In this research, PsycINFO was chosen because it is considered as the most expansive indexing database in the behavioral sciences and mental health, and has been referred to by many other scoping review articles (Piškur et al., 2012; Levac, Rivard, \& Missiuna, 2012; Stevens, Kirsh \& Nixon, 2014).

\section{Method}

\section{Scoping Review}

Scoping review is a relatively new but effective method to map relevant literature in a specific field. Similar to systematic reviews and meta-analyses, it is considered strong enough to stand as a research (Arksey \& O'Malley, 2005). A scoping review conducted to see the progress of the method itself, shows that as many as $74.1 \%$ from total 344 scoping review articles are addressed to a health topic, including psychology, highlighting the popularity of such method (Pham et al., 2014). The five stages scoping review framework will be used in this study: (1) Identifying the research question; (2) Identifying the relevant studies; (3) Selecting the studies; (4) Charting the data; and (5) Collating, summarizing and reporting the results (Arksey \& O'Malley, 2005).

\section{Study Inclusion and Exclusion Criteria}

For studies to be included in the review, they had to meet following inclusion criteria: (a) Author or one of the authors is an Indonesian scholar (citizen). The position of the authorship will not decide the inclusion process in this study to ensure all articles authored by at least one Indonesian scholar are included. Limiting the articles to only articles with Indonesian first author will extremely narrow down the scope, potentially finding very few to none articles. To check on the citizenship, author names will be checked by a search engine; in this research we used Google; (b) The study is concerning Indonesia and its people; (c) The attribute of the study (method, theory, literature) is dominantly psychology; (d) If the article meets the following criteria, they will be excluded: It is not a research report in an academic journal (book, in-depth 
review, editorial, theses. etc.). We decide to include only study conducted by Indonesian scholars and concerning Indonesia to make sure we located studies that will represent the current development of psychology in Indonesia (by its people and for its people). Only research reports in an academic journal will be included to specifically trace the strength of psychology research related to journal publication in Indonesia.

\section{Search Terms and Strategies}

An initial orientation search was conducted in PsycINFO database to extract the key search terms. The search strategies used with following formula (see Table 1).

Psychology term was exploded to ensure it include all narrower terms such as "Abnormal Psychology," "Experimental Psychology," "Mathemathical Psychology." Exploding is a unique method in searching a database. Exploding a subject heading is necessary to search all narrower subject headings under the selected subject heading (UCL, 2011). The code .ab and ti used to make a thorough search in abstract and title section of the articles. Term of large islands and regions in Indonesia such as "Java," "Sulawesi," and "Lesser Sunda Islands" were included to make sure more articles concerning Indonesia could be traced in the searching process. Classic terms such as "Madoera" and "Irian Jaya" were also included to avoid missing the classic research concerning Indonesia.

The search steps were as follows: open the advanced search window in PsycINFO, make sure to clear all search history, type "exp psychology" and then click on search, copy and paste all terms under Indonesia and then click on search, use the search history box to combine selections with "AND", and then click on search. EndNote X7 for Mac application was used to organize the results.

\section{Study Selection}

Two reviewers (IYK, BNB) independently evaluated and decided which title to include and exclude by categorizing them as relevant, not relevant and possibly relevant. After that, study abstracts that considered relevant and possibly relevant were evaluated by IYK first and then cross-checked by BNB. Next, full-text articles were reviewed by IYK first and then cross-checked by BNB. IYK has experiences in doing scoping review and systematic review before. IYK has also learned directly how to develop search strategies and conduct searches in PsycINFO database from an expert librarian in psychology field working at a university in Australia. BNB has basic knowledge regarding scoping review and its step-by-step framework.

\section{Results}

The search identified 70 records, with 60 excluded based on the titles. Some notes in studies excluded in this process are: (1) A lot of studies were conducted in Indonesia with Indonesians as its subjects, but the writers are not originally from Indonesia. An example of the study is "Towards an indigenous psychology of religious terrorism with global implications: Introduction to AJSP's special issue on Islamist terrorism in Indonesia" (Liu \& Woodward, 2013); (2) Some results are written by Indonesian scholars but in a form of book chapter, not a research article in an academic journal. Therefore they are immediately excluded. An example of this is "The Subject of Mental Illness: Psychosis, Mad Violence, and Subjectivity in Indonesia" (Good, Subandi \& Good, 2007).

Next, 10 abstracts were examined, with five excluded from the study. Some notes in studies excluded in this process were: (1) The article

Table 1

Search Terms

\begin{tabular}{cl}
\hline Psychology & \multicolumn{1}{c}{ Indonesia } \\
\hline & Indonesia.ab. or Indonesia.ti. or Java.ab. or Java.ti. or Borneo.ab. or Borneo.ti. or Kalimantan.ab. or \\
& Kalimantan.ti. or Sumatra.ab. or Sumatra.ti. or Celebes.ab. or Celebes.ti. or Sulawesi.ab. or \\
& Sulawesi.ti. or West Irian.ab. or West Irian.ti. or Indonesian New Guinea.ab. or Indonesian New \\
& Guinea.ti. or Irian Jaya.ab. or Irian Jaya.ti. or West Papua.ab. or West Papua.ti. or Madoera.ab. or \\
& Madoera.ti. or Madura.ab. or Madura.ti. or Bali.ab. or Bali.ti. or Nusa Tenggara.ab. or Nusa \\
& Tenggara.ti. or Lesser Sunda Islands.ab. or Lesser Sunda Islands.ti. or Mollucas.ab. or Mollucas.ti. \\
& or Maluku.ab. or Maluku.ti.
\end{tabular}


"Behavioral, ecological, and evolutionary aspects of meat-eating by Sumatran orangutans (Pongo abelii)" (Hardus et al., 2012) was excluded because of the low emphasis on behavioral aspects of the orangutan; (2) Articles like "Ethics, economics and environmental complexity: The mud flow disaster in East Java" (Muhtada, 2008) and "A framework for understanding old-age vulnerabilities" (Schroder-Butterfill \& Marianti, 2006) was excluded since it is not a research report but an in-depth review. This highlighted importance of triple checking from title to abstract to full-text to ensure that all relevant articles are included and all irrelevant studies are excluded; (3) The theses "Impact of occupational health interventions in Indonesia" (Denny, 2013) and "The quest for unity-indiversity: Identity and growth in Paul, Erikson, and the churches of Santapan Rohani Indonesia. (Erik H. Erikson)" (Malik, 2000) were excluded because it is a theses for $\mathrm{PhD}$ program.

Next, five abstracts were examined and only one study was excluded from this scoping review process. The article "Regime Shifts in Balinese Subaks" (Lansing et al., 2014) was removed from the study because it had a heavy emphasis in ecological context with minimum attention put in the psychological perspective. Total of four articles were included in the scoping review. Figure 1 describes the scoping review study selection process.

\section{Description of the Included Studies}

Interestingly, three of the studies were categorized under the same theme, cross-cultural psychology (Liem, Martin, Nair, Bernardo, \& Prasetya, 2011; Schwarz et al., 2010; R. Oerter, R.M. Oerter, Agostiani, Kim, \& Wibowo, 1996). Two of them (Liem et al., 2011; Schawz et al., 2010) even published in the same journal, that is the Journal of Cross-Cultural Psychology. One of the study (Aditama et al., 2008) is about tobacco control in Indonesia, a public health issue that is closely related to the subfield of health psychology. All articles had been published between 1996 and 2011. Two studies used quantitative research methods and two others used a qualitative approach with interview as the main data gathering technique. All four of the studies had more than three investigators; all of them are combinations between Indonesian scholars and overseas scholars. The Indonesian scholars came from Maranatha Christian University, University of Indonesia, and Padjajaran University. All of them are located in the western part of Java Island. A descriptive summary could be found in Table 2 .

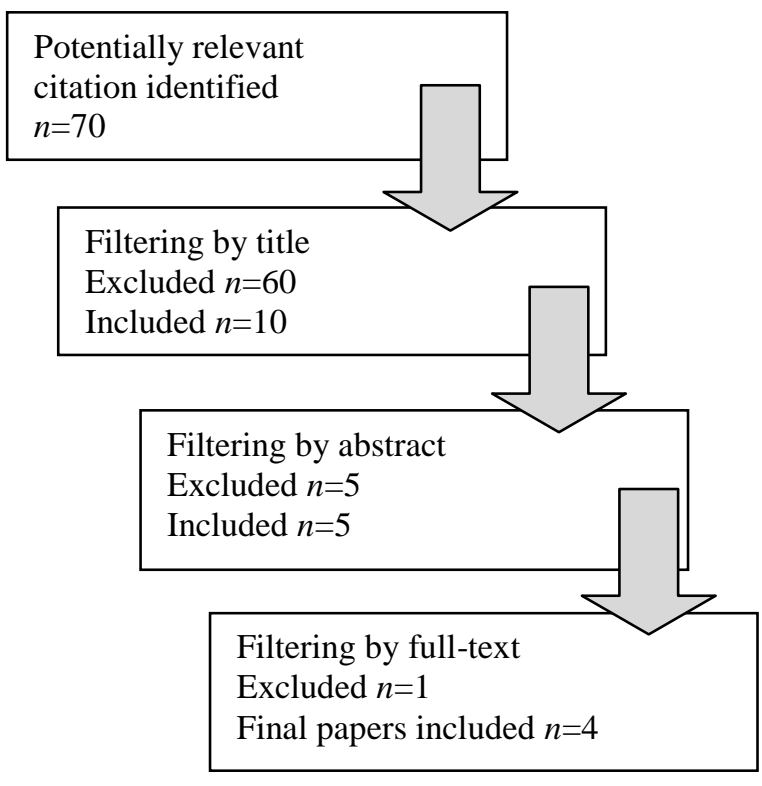

Figure 1. Scoping review study selection process.

\section{Discussion}

This scoping review aimed to locate existing psychology studies that are Indonesian-based in terms of location and writer and indexed by PsycINFO, a high quality psychology articles database. After a systematic search and filtering process, four studies were included in the review and have been described. The analysis process on four included and other excluded studies resulted in some important points:

\section{Several Articles in Indonesian Topic were Written by Overseas Scholars}

Considered as a "giant laboratory," Indonesia has a lot of resources that could be used as research material. This is realized by both Indonesian and overseas scholars. The article by Liu and Woodward (2013) shows us that the researchers have a deep interest in religious terrorism, an issue that is unique to only few countries, including Indonesia. Article from DunbarHall (2011) that explored how children learn dance and music in Bali further shows us that there are plenty of topics that could be discussed and explored in Indonesia. It is also intriguing how they can still manage to do a complete analysis and research regarding Indonesia, considering it is quite complicated for a foreign researcher to gain permit to do research in this country (UGM, 2010). 
Table 2

Characteristics of Included Studies

\begin{tabular}{|c|c|c|c|c|}
\hline Author and Setting & Aim of the Study & Study Design & Population & $\begin{array}{l}\text { Psychology } \\
\text { Focus }\end{array}$ \\
\hline $\begin{array}{l}\text { Liem, G. A. D., Martin, A. J., Nair, E., } \\
\text { Bernardo, A. B. I. \& Prasetya, P. H. } \\
2011 \\
\text { Singapore, Philippines, Indonesia, } \\
\text { Australia }\end{array}$ & $\begin{array}{l}\text { Examine the content } \\
\text { and structure of } \\
\text { values of middle } \\
\text { adolescents }\end{array}$ & $\begin{array}{l}\text { Quantitative } \\
\text { Questionnaire's } \\
\text { item } \\
\text { intercorrelations }\end{array}$ & $\begin{array}{l}920 \\
\text { adolescents } \\
\text { aged } 16 \text { years } \\
\text { old }\end{array}$ & $\begin{array}{l}\text { Cross- } \\
\text { cultural } \\
\text { Psychology }\end{array}$ \\
\hline $\begin{array}{l}\text { Aditama, T. Y., Pradono, J., Rahman, } \\
\text { K., Warren, C. W., Jones, N. R., Asma, } \\
\text { S., Lee, J. } \\
2008 \\
\text { Indonesia }\end{array}$ & $\begin{array}{l}\text { Analyze The } 2006 \\
\text { Indonesia Global } \\
\text { Youth Tobacco } \\
\text { Survey }\end{array}$ & $\begin{array}{l}\text { Quantitative } \\
\text { Descriptive } \\
\text { analysis }\end{array}$ & $\begin{array}{l}4635 \text { students } \\
\text { in secondary } \\
\text { grades } 1-3, \\
\text { aged } 13-15 \\
\text { years old }\end{array}$ & $\begin{array}{l}\text { Health } \\
\text { Psychology }\end{array}$ \\
\hline $\begin{array}{l}\text { Schwarz, B., Albert, I., Trommsdorff, } \\
\text { G., Zheng, G., Shi, S., Nelwan, P. R. } \\
2010 \\
\text { China, Indonesia, German }\end{array}$ & $\begin{array}{l}\text { Compare } \\
\text { intergenerational } \\
\text { support and life } \\
\text { satisfaction of elderly } \\
\text { mothers }\end{array}$ & $\begin{array}{l}\text { Qualitative } \\
\text { Interview }\end{array}$ & $\begin{array}{l}406 \text { elderly } \\
\text { mothers }\end{array}$ & $\begin{array}{l}\text { Cross- } \\
\text { cultural } \\
\text { psychology }\end{array}$ \\
\hline $\begin{array}{l}\text { Oerter, R., Oerter, R.M., Agostiani, } \\
\text { H., Kim, H.-O., Wibowo, S. } \\
1996 \\
\text { United States, Indonesia, Japan, } \\
\text { Korea }\end{array}$ & $\begin{array}{l}\text { Explore and } \\
\text { compare the concept } \\
\text { of human nature }\end{array}$ & $\begin{array}{l}\text { Qualitative } \\
\text { Interview } \\
\text { Content analysis }\end{array}$ & $\begin{array}{l}342 \text { young } \\
\text { adults aged } \\
\text { between } 18 \text { to } \\
25 \text { years old }\end{array}$ & $\begin{array}{l}\text { Cross- } \\
\text { cultural } \\
\text { psychology }\end{array}$ \\
\hline
\end{tabular}

These two articles also showed us that topics that are closely related to cultural issues were considered interesting by foreign researchers to explore. Some of their works have also been instrumental for Indonesian people to understand more about themselves. Notice how Fox's (1980) work has been monumental in explaining the human life in Eastern Indonesia, especially East Nusa Tenggara province. Such studies act as reminders for Indonesian scholars to catch up with their foreign counterparts; otherwise we will only become consumers of foreign works in the academic field.

\section{Indonesian Scholars were Doing Well in Writing In-depth Reviews and Book Chapters}

This is shown by the fact that there were many important topics explored by Indonesian scholars, for example the book chapter from Muluk and Malik (2009) discussed lessons learned from the "Baku Bae" Peace Movement implemented in the Mollucas. This chapter provided an insight in peace psychology that is contextual within an Indonesian setting. Another example is a chapter from Good, Subandi and Good
(2007) that explores the topic of mental illness in Indonesia. We thought that Muluk and Malik's (2009) chapter are slightly better though, since both writers are Indonesians. This indicated that they have put more effort in writing the chapter, since English is not their first language.

Aside from these two chapters, Sarwono's (2004) chapter "Psychology in Indonesia" was also indexed by PsycINFO. This made us speculate that most of the chapters were written because they were requested by someone else other than the writer. Nevertheless, with these book chapters and some literature review articles (Muhtada, 2008; Schroder-Butterfill \& Marianti, 2006), we can safely say that Indonesian scholars were good in making their in-depth articles indexed by PsycINFO.

\section{Theses for PhD are Good Enough, If?}

We noted that the theses from Denny (2013), Malik (2000), and Siscawati (2013) are done in overseas universities, respectively University of South Florida, Boston University and University of Washington. All of these universities are located in the United States of 
America. This may be caused by a good management in publishing, since the publisher for all three theses are the same, Dissertation Abstracts International.

Indonesia should learn from this phenomenon; higher education institutions in Indonesia should strive to produce better theses and also make them bilingual so the international community could consume our academic products, too. Founding a specific journal to organize dissertations produced by universities in Indonesia could become a solution if we are prepared enough. These journals may help organize and improve the quality of produced theses up to international standards. We conclude that currently theses for $\mathrm{PhD}$ that are produced by Indonesians could be good enough to be indexed by PsycINFO if there are specific journals and/or publishers that focused in theses publications.

\section{More than half of the included studies focused on cross-cultural psychology}

This finding is actually closely related to a pattern mentioned in the first discussion, overseas scholars loved to explore Indonesian cultures. Exploring this theme mean they could find novelty in their study, an attribute that is very important for an article to be considered of high quality. It is also interesting how all three studies were comparing the results mined in Indonesia to results from other culture, and in order to get good results, a large number of samples were obtained (all studies had above 300 subjects). The comparisons gave another point in their research's strength, increasing the probability of being published in a high quality journal.

As a matter of research method, both qualitative and quantitative share a same number of studies. This showed that both approaches have similar potentials to help a study get published in a high quality journal, even though the international psychology community has the tendency to favor quantitative approach more than qualitative (Prawitasari, 2006). These four relevant studies also showed that children, or to be more specific, adolescents is a favored age group to become target of the studies, as they were shown to be the sample for two relevant studies (50\%).

An important point to discuss is how all four studies were written by multi-nationality writers. This could be caused by several reasons: Firstly, data from more than one nation boosts the reliability and usefulness of the data, which in turn increases a research value (WHO, 2003). This is important for future publishing efforts. Secondly, data from multiple nations make it is easier to achieve saturation in qualitative research and also easier to gain a lot of participants in quantitative research. Both are important for the value of the research. As Cohen (1988) stated that larger sample size and larger population effect means stronger data. WHO's Report on Disability (2011) is an example of how data gathered from multiple nations further strengthen the value and impact of the research. Thirdly, by gaining the support of Indonesian scholars, overseas scholars won't have to struggle to get a research permit before they can begin their research. An example of this point came from Kupang, East Nusa Tenggara Province. Memorandum of Understanding between University of Nusa Cendana and The Flinders Overseas Health Group (FOHG) from Australia made FOHG members save a lot of efforts to do a collaborative research (UTAS, 2015). University of Nusa Cendana's staff had helped them in getting the permit from inside Indonesia (writer's communication with a faculty member at University of Nusa Cendana, 2015). Fourthly, related to the third reason, sometimes there is a possibility that overseas scholars want to put ethical burdens on Indonesian scholar's shoulder. High-risk research (such as research with children, person with disability, and disadvantaged group) can sometimes bring adverse situations to researchers if they are not careful, and by working with local scholars, overseas scholars could avoid these risks altogether. For example, a team of medical doctors from Australia has provided medical surgery in West Timor, Indonesia (Akoit, 2008), even when the health authority of Indonesia have stated that they never gave any permit for foreign doctors to conduct medical practices (Angelina, 2014). Fifthly, Indonesian scholars won't bother with self-improvement process; they may treat these kinds of research as a shortcut to get international publication easily. They benefit from free proofreading services and recognition from the publication for this research (writer's communication with fellow scholar in Indonesia, 2014).

\section{Lack of Good Quality Research by Indonesian Scholars}

PsycINFO is an abstract of psychological literature back from the 1800s to the current time (Bell, 2015). Finding only four research articles that is authored or co-authored by Indonesian scholars from more than 3.7 million records (APA, 2015) means that Indonesian psychologists and psychology scholars are still lacking in publishing good quality research. This may be caused of low proficiency in English, lack of skill and 
knowledge and unsupportive academic culture. DIKTI's effort to improve the number of international publications (Syarat Lulus S-1, 2012) may set the academic culture needed to boost the number of international publications. Scholarship program for Indonesian scholars such as Indonesia Endowment Fund for Education (LPDP, 2015) may help address the lack of skill and knowledge needed to produce high quality research. Additionally, the issue regarding the lack of English proficiency should be addressed from as early as early childhood education posts to university setting.

To improve the level of research in the specific field of clinical and health psychology, Indonesian scholars and psychologists may consider conducting research that could bring a high level of evidence. The Joanna Briggs Institute provided an evidence hierarchy that could act as a guide for researchers (JBI, 2014). This hierarchy listed systematic reviews of randomized controlled trials as the highest level of evidence. Indonesian scholars can consider enhancing their experience and knowledge to conduct a systematic review and/or a randomized controlled trial in order to be able to produce a good quality research. Learning to conduct a scoping review is also useful to determine whether a systematic review is needed or not (Arksey \& O'Malley, 2005). Comprehensive effort from all related stakeholders hopefully will improve not only the quantity of the international publications but also its quality.

\section{Limitations}

This study has its limitations; the first identified limitation is there were only two reviewers for this study. To add more reviewers in a scoping study could reduce the probability of missing out potential relevant articles (Arksey \& O'Malley, 2005). Further scoping reviews should try to involve three or more experienced reviewers to increase the quality of the study. It is also important to notice that scoping review is a relatively new method that has not been done regularly in Indonesia, which makes it harder to find an experienced Indonesian reviewer. Searching a less complicated database such as Scopus could bring the experience needed by Indonesian scholars to do a more complicated scoping review.

The second limitation is that since there was only one database searched (PsycINFO), there will be a chance of missing high quality research articles. There is a possibility that psychological research articles published by other field's journals such as education and social field journal may not be indexed by PsycINFO but indexed by other specialized databases such as Educational Resources Information Center (specializing in education field) and Sociological Abstracts (specializing in social and other humanistic studies instead (Bell, 2015). The consequence from this limitation is that this review may not accurately describe the existing high quality published work from Indonesian psychologists and psychology scholars. Further study could consider searching those specialized databases or broader and more general database such as Scopus and Web of Science (Bell, 2015) to track more high quality Indonesian psychological research articles. Since Google Scholar is useful for tracking grey literatures (Bell, 2015), it is not recommended for a scoping review with purpose of indexing published good articles.

\section{Conclusion}

This study is considered among the first scoping study that has been done by Indonesian people and in Indonesian context. Scoping review in this study showed us that there are not many psychologyfocused researches from Indonesian researchers that were published in high quality journals. All of these high quality research articles were even published cooperatively with scholars from other countries. This showed us that psychology scholars in Indonesia still need more improvements to be able to contribute more in international stage. We should consider utilizing our unique and rich cultural resources more to become better in research. Exploring unique concepts in Indonesia such as keter (an indigenous term related to courage and responsibility) in Minahasa or minu ae petu (an indigenous term to describe collectiveness of the community) in East Nusa Tenggara can give the novelty needed in our research while simultaneously introduce and strengthen our culture's influence in international forum (Tigadanauwarna, 2013; LukensBull, 1999). Conducting scoping review in the psychology field of Indonesia is highly useful to get answer for "what has been done?" and "what to do next?" questions. Unfortunately, not every university in Indonesia has access to important databases in the field. This is to be addressed so that the span of our research will get better in the future.

\section{References}

Aditama, T. Y., Pradono, J., Rahman, K., Warren, C. 
W., Jones, N. R., Asma, S., \& Lee, J. (2008). Linking global youth tobacco survey (GYTS) data to the WHO framework convention on tobacco control (FCTC): The case for Indonesia. Preventive Medicine: An International Journal Devoted to Practice and Theory, 47(Suppl1), S11-S14.

Akoit, J. (2008). 150 pasien di TTU dioperasi gratis. Retrieved from http://spiritentete .blogspot.com/ 2008/12/150-pasien-di-ttu-dioperasi-gratis.html

Angelina, Y. (2014). Ada dokter asing praktek di Indonesia? Itu ilegal. Retrieved from http://www. tabloidnova.com/Nova/Kesehatan/Umum/AdaDokter-Asing-Praktek-di-Indonesia-Itu-Ilegal/

APA (2015). PsycINFO ${ }^{\circledR}$. Retrieved from http:// www.apa.org/pubs/databases/ psycinfo/index.aspx

Arksey, H., \& O’Malley, L. (2005). Scoping studies: Towards a methodological framework. International Journal of Social Research Methodology, 8(1), 19-32.

Beall, J. (2015). List of publishers. Retrieved from http://scholarlyoa.com/publishers/

Bell, M. (2015). Psychology: Databases. Retrieved from http://libguides.adelaide. edu.au/c.php?g= $165080 \& \mathrm{p}=1083368$

Cohen, J. (1988). Statistical power analysis for the behavioral sciences. Hillsdale, NJ: Lawrence Erlbaum.

Denny, H. M. (2013). Impact of occupational health interventions in Indonesia. Dissertation Abstracts International: Section B: The Sciences and Engineering, 74(5-B(E)), No Pagination Specified.

Dunbar-Hall, P. (2011). Children's learning of music and dance in Bali: An ethnomusicological view of the cultural psychology of music education. In M. S. Barrett (Ed.), A cultural psychology of music education (pp. 17-40). New York, NY: Oxford University Press.

Fox, J. J. (1980). The flow of life: Essays on Eastern Indonesia. Cambridge: Harvard University Press.

Good, B. J., Subandi, \& Good, M.-J. D. (2007). The subject of mental illness: Psychosis, mad violence, and subjectivity in Indonesia. In J. Biehl, B. Good, \& A. Kleinman (Eds.), Subjectivity: Ethnographic investigations (pp. 243-272). Berkeley, CA: University of California Press.

Hardus, M. E., Lameira, A. R., Zulfa, A., Atmoko, S., de Vries, H., \& Wich, S. A. (2012). Behavioral, ecological, and evolutionary aspects of meat-eating by Sumatran orangutans (Pongo abelii). International Journal of Primatology, 33(2), 287-304.

HIMPSI (2013). Sekilas Himpsi. Retrieved from http://himpsi.or.id/index.php/organisasi/sekilashimpsi
JBI. (2014). New JBI levels of evidence. Retrieved from http://joannabriggs.org/assets/docs/approach /JBI-Levels-of-evidence_2014.pdf

Lansing, J., Cheong, S. A., Chew, L. Y., Cox, M. P., Ho, M.-H. R., \& Arthawiguna, W. A. (2014). Regime shifts in Balinese Subaks. Current Anthropology, 55(2), 232-239.

Levac, D., Rivard, L., \& Missiuna, C. (2012). Defining the active ingredients of interactive computer play interventions for children with neuromotor impairments: A scoping review. Research in Developmental Disabilities, 33, 214223. Doi: 10.1016/j.ridd.2011.09.007

Liem, G. A. D., Martin, A. J., Nair, E., Bernardo, A. B., \& Prasetya, P. H. (2011). Content and structure of values in middle adolescence: Evidence from Singapore, the Philippines, Indonesia, and Australia. Journal of Cross-Cultural Psychology, 42(1), 146-154.

Liu, J. H., \& Woodward, M. (2013). Towards an indigenous psychology of religious terrorism with global implications: Introduction to AJSP's special issue on Islamist terrorism in Indonesia. Asian Journal of Social Psychology, 16(2), 79-82.

LPDP. (2015). Beasiswa. Retrieved from http://www .lpdp.depkeu.go.id/beasiswa/

Lukens-Bull, R. (1999). Review of Saya S. Shiraishi 'Young Heros: The Indonesian family in politics.' The Journal of Asian Studies, 58, 579-581.

Oerter, R., Oerter, R.M., Agostiani, H., Kim, H.O., \& Wibowo, S. (1996). The concept of human nature in East Asia: Etic and emic characteristics. Culture \& Psychology, 2(1), 9-51.

Malik, D. K. (2000). The quest for unity-in-diversity: Identity and growth in Paul, Erikson, and the churches of Santapan Rohani Indonesia. (Erik H. Erikson). Dissertation Abstracts International Section A: Humanities and Social Sciences, 61(5A), 1894.

Muhtada, D. (2008). Ethics, economics and environmental complexity: The mud flow disaster in East Java. Systems Research and Behavioral Science, 25(2), 181-191.

Muluk, H., \& Malik, I. (2009). Peace psychology of grassroots reconciliation: Lessons learned from the "Baku Bae" peace movement. In C. J. Montiel, \& N. N. Noor (Eds.), Peace psychology in Asia (pp. 85-103). New York, NY: Springer Science + Business Media; US.

Munandar, S. C. U. \& Munandar, A. S. (1987). Psychology in Indonesia: Its past, present and future. In G. H. Blowers \& A. M. Turtle (Eds.), Psychology moving East: The status of Western 
psychology in Asia \& Oceania. Boulder, Colorado: Westview Press.

Pham, M. T., Rajić, A., Greig, J. D., Sargeant, J. M., Papadopoulos, A., \& McEwen, S. A. (2014). A scoping review of scoping reviews: Advancing the approach and enhancing the consistency. Research Synthesis Methods, 5, 371-385. doi: 10.1002/jrsm.1123

Piškur, B., Beurskens, A. J. H. M., Jongmans, M. J., Ketelaar, M., Norton, M., Frings, C. A.,... Smeets, R. J. E. M. (2012). Parents' actions, challenges, and needs while enabling participation of children with a physical disability: A scoping review. $B M C$ Pediatrics,12, 177. Retrieved from http://www. biomedcentral. com/1471-2431/ 12/177

Prawitasari-Hadiyono, J. E. (1998). Behavior therapy in Indonesia. In Tian P.S. Oei (Ed.). Behavior therapy in Asia. Glebe, NSW, Australia: Edumedia, Pty. Ltd.

Prawitasari, J. E. (2006). Psikologi Nusantara: Ke sanakah kita menuju? Buletin Psikologi, 14(1), 1-30.

Sarwono, S. W. (2004). Psychology in Indonesia. In M. J. Stevens, \& D. Wedding (Eds.), Handbook of international psychology (pp. 453-466). New York, NY: Brunner-Routledge; US.

Schroder-Butterfill, E., \& Marianti, R. (2006). A framework for understanding old-age vulnerabilities. Ageing \& Society, 26(1), 9-35.

Schwarz, B., Albert, I., Trommsdorff, G., Zheng, G., Shi, S., \& Nelwan, P. R. (2010). Intergenerational support and life satisfaction: A comparison of Chinese, Indonesian, and German elderly mothers. Journal of Cross-Cultural Psychology, 41(5-6), 706-722.
Siscawati, M. (2013). Social movements and scientific forestry: Examining the community forestry movement in Indonesia. Dissertation Abstracts International Section A: Humanities and Social Sciences, 74(2-A(E)), No Pagination Specified.

Stevens, M., Kirsh, B., \& Nixon, S. A. (2014). Rehabilitation interventions for children living with HIV: A scoping review. Disability and Rehabilitation, 36(10), 865-874.

Syarat lulus S-1, S-2, S-3: Harus publikasi makalah. (2012). Kompas.com Retrieved from http:// edukasi.kompas.com/read/2012/02/03/09280630/S yarat. Lulus.S-1.S-2.S-3.Harus.Publikasi.Makalah

Tigadanauwarna. (2013). "Minu ae petu": Tradisi ekonomi gotong royong masyarakat Ende Lio, yang tak hilang oleh waktu. Retrieved from http:// tigadanauwarna.blogspotcom/2013/06/minu-aepetu-tradisi-ekonomi-gotong.html

UCL. (2011). PsycINFO on OvidSP. Retrieved from https://www.ucl.ac.uk/ich/ services/library/training _material/psycinfo_on_ovidsp.pdf

UGM. (2010). Izin penelitian di Indonesia masih berbelit-belit. Retrieved from http://www.ugm. ac.id/id/post/page?id=3037

UTAS. (2015). Kupang, Indonesia. Retrieved from http://www.utas.edu.au/ medicine/ medicine/ programs/smile/y4-electives/places/kupang

WHO. (2003). Improving data quality: A guide for developing countries. Retrieved at $1^{\text {st }}$ of June 2015 from http://www.wpro.who.int/ publications/docs/ Improving_ Data_Quality.pdf

WHO (2011). World report on disability. Malta: WHO Press. Retrieved from http://www.who.int/ disabilities/world_report/2011/report.pdf 